\title{
Empirical Analysis on the Influence of Business Environment on Foreign Direct Investment Inflow Based on the Panel Data on 26 Countries
}

\author{
Jiang Wang, Zhendong $\mathrm{Li}^{*}$, Xueying Sun \\ School of Economics and Management, Beijing University of Technology, Beijing 100022, China
}

Corresponding Author Email: LiZD@emails.bjut.edu.cn

https://doi.org/10.18280/ijsdp.150808

Received: 10 June 2020

Accepted: 8 September 2020

\section{Keywords:}

foreign direct investment (FDI), business environment, location advantage, empirical analysis

\begin{abstract}
With the intensification of global competition and development of investment theories, foreign direct investment (FDI) is no longer solely affected by economic factors. Many noneconomic factors, such as policies and institution, now play an important role in FDI inflow. As a composite indicator, business environment has attracted a growing attention from investors. From theoretical and empirical perspectives, this paper quantifies and qualifies the influence of business environment over the FDI under different conditions. The impact mechanism of business environment on the FDI was refined by decomposing business environment into multiple subfactors, and considering various factors of different economies, such as natural resources (NR), technological resources (TR), and political stability (PS). An empirical analysis was conducted on the panel data of 26 countries in 2005-2018. The results show that: the host country can attract more FDI inflow by improving business environment, NR, TR, and PS; excessively high NR and TR, to a certain extent, suppress the promotion effect of business environment on FDI; four subfactors of business environment, namely, the protection of small and medium investor (PI), cross-border trade (CT), electricity supply (ES), and insolvency (IN), have relatively high promotion effects on FDI inflow. The research results enrich the theories on FDI and business environment, and provide a reference for the design of innovative polices.
\end{abstract}

\section{INTRODUCTION}

Foreign direct investment (FDI) provides economies with an important tool of economic cooperation, and brings many benefits to the host country. Many scholars agree that the FDI can boost the production capacity and efficiency of the host country through its competitive effect and technology spillover, creating more jobs for the labor force. In addition, the FDI could possibly improve the wage level, accelerate the trade development, and optimize the economic structure of the host country.

Despite the various benefits, the global FDI scale is shrinking. As of 2018, the global FDI flow dropped by $13.37 \%$ year-on-year, and had been growing negatively for three years in a row. The FDI stock witnessed another decline after the 2008 financial crisis. The FDI scale in different economies decreased across the board. Compared with developing economies, developed economies faced violent fluctuations in FDI flow.

Therefore, economies around the world competed to attract foreign capital. Many of them laid down various incentive policies on foreign investment. However, the FDI growth remained weak. Overall, the number of investment promotion policies was $14 \%$ fewer than that in 2014 , albeit exhibiting an upward trend. Most countries attached increasing importance to the restriction and control of foreign capital, with the aim to ensure national security, or protect the core technologies and resources of strategic industries by limiting the foreign ownership of domestic resources. The investment policies formulated by different countries are highly unpredictable, making the investment environment uncertain and instable. This, coupled with the rise of investment protectionism, makes it difficult for economies to achieve their investment goals.

Against this backdrop, it is necessary to broaden the horizon and consider other policy factors, such as the business environment. In fact, more and more research has been conducted based on the annual briefings by the World Bank on business environment. The empirical analysis on how business environment, especially its subfactors, affect FDI inflow helps to pinpoint the defects in business environment, and identify the starting point for improving that environment.

With the development of related theories, China has further relaxed investment access and optimized the business environment. For instance, several laws and policies have been issued to attract the FDI, including The Catalogue of Industries for Encouraged Foreign Investment (2019 Edition), The Special Management Measures for Foreign Investment Access (Negative List) (2019 Edition), and Foreign Investment Law.

As the location advantage of a country, the business environment theoretically facilitates the production and operation of investors in the host country, making their activities more cost effective. Investors will turn the location advantage into their own competitive advantage, and obtain higher profits and returns in the host country. Therefore, the business environment is a location advantage of the host country. Better business environment will attract more FDI inflow. Nevertheless, the attraction largely depends on factors 
like the economic development and resource endowment of the host country. Moreover, the business environment is a comprehensive index, involving multiple subfactors. These subfactors influence the FDI in different degrees and aspects.

Most of the existing studies on business environment start from the site selection of FDI. In this paper, business environment and FDI are investigated from a new perspective: the integration between "going out" and "brining in". In addition, researchers engaged in the influencing factors of the FDI are increasingly aware of the importance of soft environment factors like policies. But only a few scholars have explored the index of business environment. The business environment has been mainly interpreted with business environment ranking as the dependent variable. The few studies that take business environment score as an independent variable fail to consider the effect of the interaction term. To solve the problem, this paper examines previous data on the attraction of FDI inflow by business environment, laying the basis for variable and model selection of empirical analysis.

From the perspective of the host country, this paper studies how the improvement of the business environment attracts more FDI inflow, providing new evidence to the relevant research. Moreover, an empirical analysis was conducted on the panel data of 26 countries in 2005-2018. Specifically, the business environment was decomposed into multiple subfactors. Using the popular empirical method of regression analysis on panel data, the authors evaluated the impact of the subfactors and several control variables (e.g., natural resources, and technological resources) on the FDI, and detailed the impact mechanism of business environment on FDI, which makes up the defects of the previous research.

The remainder of this paper is organized as follows: Section 2 reviews the relevant literature; Section 3 selects the variables, sets up a model, conducts an empirical analysis, and analyzes the analysis results; Section 4 puts forward the conclusions and targeted suggestions.

\section{LITERATURE REVIEW}

The FDI theory roughly evolves through three stages. In the first stage, the representative theories are monopolistic advantage theory proposed by S.H. Hymer and expanded by C.P. Kindleberger, and product life-cycle theory proposed by Raymond Vernon. According to the monopolistic advantage theory, in an imperfect competition market, an enterprise with monopolistic advantage will directly invest in other countries to make the most of its advantage. The advantages of the multinational enterprise in trademark, technology, and economies of scale can offset the competitive advantages of the enterprises in the host country. The product life-cycle theory divides the life-cycle of a product into three phases: innovation, maturation, and standardization. The three-phase paradigm explains the motivation, timing, and location of investment by an enterprise depending on its production and competition conditions, and discloses the reason for the surging FDI of American enterprises after the Second World War (WWII).

The second stage is represented by J.H. Dunning's eclectic theory of international production [1]. This theory holds that an enterprise cannot implement outward foreign direct investment (OFDI), without advantages in ownership, internalization, and location. Among them, the location advantage fully explains the factors affecting the FDI attraction by the host country, namely, geographic location, factor price, market maturity, demand scale, policy adjustment, and government intervention. On the location selection of multinational enterprises, Dunning classified the investor motivations into four categories: market-seeking, resourceseeking, efficiency-seeking, and strategic asset-seeking. This classification method has been used until now. Each kind of motivation corresponds to several variables, which reflect the location advantage of the host country in attracting FDI inflow.

First, the resource-seeking FDI focuses on the quality, scale, and price of raw materials. All these factors are related to the establishment and operating costs of multinational enterprises. The relevant research often tackles such variables as natural resources, infrastructure quality, and logistics cost. Asiedu [2] empirically analyzed natural resources against the panel data of 22 countries in 1984-2000, revealing that natural resources can promote the inflow of FDI. Song and Wu [3] studied OFDI location selection by state-owned enterprises (SOEs), and proved that SOEs prefer to implement OFDI in host countries with rich natural resources.

Second, market-seeking FDI usually flows to regions with greater demand. A large demand promises a high profitability. The factors related to demand include market size, consumption, income, employment, etc. Yan and Liu [4] empirically analyzed the influencing factors of FDI inflow in China's producer service industry, based on the provincial panel data of 2004-2010, and concluded the FDI in the producer service industry is positively correlated with the following factors: the growth rate of regional gross domestic product (GDP), which consists of the market size and growth potential; the number of graduates from secondary vocational schools and colleges, measured by the number of skilled labor; the mean wage of the industry; the total import-export volume of the region.

Third, strategic assets are generally associated with the investment in innovative research and development (R\&D), the number of applications for patented technologies, and the intellectual property protection (IPP) in the host country. Markusen [5] theorized the complex influence of enhanced IPP on multinational enterprises: the enhanced IPR consolidates the investor's advantages in own technologies and property rights, making these rights exclusive, and amplifies the location advantage of the host country/region, enabling it to guarantee the effective operation of multinational enterprises; However, the enhanced IPP weakens the internalization advantage, allowing foreign investors to replace the FDI with technology licensing. To sum up, the influence of IPP on FDI depends on the game between the above two promotion effects and one inhibition effect. The final empirical results demonstrate that the promotion effects outshine the inhibition effect, that is, enhanced IPP benefits the FDI inflow. This effect is relatively prominent in developed countries and in the financial industry.

Fourth, the FDI efficiency is affected by many economic and institutional factors. To be specific, the influencing factors include real interest rate, exchange rate, inflation rate, government regulation, corruption, tax incentive, establishment of free trade zones, and international investment agreements. With the aid of a semi-gravity model, Ismail [6] identified the determinants of the FDI in members of The Association of Southeast Asian Nations (ASEAN), and found that the FDI can be boosted by macroeconomic factors (e.g., low inflation, high exchange rate, and good budget management) and noneconomic factors (e.g., sound 
telecommunications infrastructure, and policy transparency). Using the gravity model, Belgibayeva and Plekhanov [7] demonstrated that, if the host country can better control corruption, more FDI will flow into that country; but this attraction effect is far weaker than the FDI attraction by a clean government. Berger et al. [8] introduced dummy variables related to bilateral investment agreements and regional trade agreements into the model, and made the following discovery: If the regional trade agreements contain relaxed access policies, the FDI inflow will increase; the existence of bilateral investment agreements also promote the FDI inflow, which can even make up for the lack of investment-related clauses in regional trade agreements.

The third stage is defined by the theory on resource-based view (RBV), which believes that foreign direct investors can gain a competitive advantage and obtain excess profits by occupying and utilizing certain key resources in the product market. Acemoglu et al. [9] established an economic system theory based on social conflict, attributed regional income differences to three aspects, e.g., economic system, geography, and culture, and regarded the system factor as the leading impactor of long-term growth of regional economy. Blonigen [10] pointed out that the competitive advantages change with time, environment, and actual conditions, and put forward the concept of strategic competition among multinational enterprises: multinational enterprises will make strategic responses, i.e., the FDI, based on their own strategic goals and changes in the objective environment. In this way, the FDI is explained clearly from the angles of advantage and motivation.

As a comprehensive index, the influence of business environment varies with investment motivation. Kolstad and Wiig [11] introduced the interaction terms between business environment and other variables to the model, and drew the following conclusions: China's OFDI is positively correlated with the business environment in the host country; the business environment suppresses the OFDI, when the investment motivation is market-seeking and resource-seeking; the business environment promotes the OFDI, when the investment motivation is strategic asset-seeking. Wang et al. [12] also confirmed that Chinese enterprises prefer to implement OFDI in countries with a good business environment: the OFDI in resource development is positively correlated with the ease of obtaining construction permits and the level of investor protection; the OFDI in commercial service is positively correlated with the degree of contract enforcement; the OFDI in local production is positively correlated with the degree of tax payment and contract enforcement; the OFDI in technological R\&D is positively correlated with the level of investor protection.

After the economy develops to a certain level, a growing attention has been paid to the influence of noneconomic factors of the FDI, and more and more scholars have shifted their focus to business environment. Jayasuriya [13] empirically analyzed the panel data of business environment rankings, FDI, and other variables in 2001-2009, and noticed that: the rising ranking of the host country in business environment generally promotes the FDI; the promotion effect is not significant but robust in developed countries, but insignificant in development countries. Morris and Aziz [14] studied the influencing factors of FDI inflow in sub-Saharan Africa and Asia, and learned from the data in 2000-2005 that property registration and cross-border trade have insignificant positive correlations with the FDI. Similarly, Contractor et al. [15] analyzed the subfactors of the business environment, and noted that more FDI flows into countries with strong contract enforcement and convenient cross-border trade; these countries satisfy the needs of investors with resource- and market-seeking motivations, owing to the low cost of contract enforcement and high efficiency of cross-border trade.

In summary, the existing studies on the FDI are mainly from two perspectives: the site selection of OFDI enterprises, and the FDI attraction by the host country. Both economic and noneconomic factors affecting the FDI have been investigated. With the slowdown of the economy, there is a growth in the reports on how noneconomic factors affect the FDI. The previous research on the influence of business environment on the FDI face the following limitations: First, the site selection of OFDI enterprises is emphasized over other issues; Second, the empirical results might not apply to the current situation, for the data are often outdated; Third, since the business environment index was not released until 2004, the data on business environment cover a short period, failing to reflect the long-term influence of business environment on the FDI; Fourth, the subjects are limited to one region, e.g., Southeast Asia, reducing the explanatory power of the results.

\section{MODELING}

\subsection{Sample selection}

\subsubsection{Country selection}

To disclose the influence of business environment on FDI inflow, the countries with a high FDI flow are of high reference value. Hence, the top 20 countries in FDI flow in 2018 were selected. To diversify the samples and enhance practicality, the top 15 source countries/regions of China's FDI, and the top 20 destination countries/regions of China's OFDI were also selected, excluding the following countries/regions:

The three tax havens, namely, the British Virgin Islands, the Cayman Islands, and the Bermuda Islands, were removed; Hong Kong, Taiwan, and Macau were also deleted, for the fuzziness of their FDIs (most of their FDIs flow back to Chinese mainland in the form of foreign capital); Samoa was discarded for the serious lack of data.

Finally, a total of 26 countries were chosen as research samples.

\subsubsection{Variable selection}

(1) Independent and dependent variables

This paper mainly tackles how the changes in the business environment affect the FDI. The impact can be measured by the ease of doing business. Therefore, the score on the ease of doing business (DB) released by the World Bank was selected as the independent variable, and the FDI stock was taken as the dependent variable [16].

The location advantages of the host country mentioned in Dunning's eclectic theory of international production, including geographic location, factor price, market maturity, demand scale, policy adjustment, and government intervention, were further refined [17]. The following subfactors of the business environment were selected from the data on 2013 2018: startup (SU), construction permit (CP), electricity supply (ES), property registration (PR), credit acquisition (CA), protection of small and medium investors (PI), tax payment (TP), cross-border trade (CT), contract enforcement (CE), and insolvency (IN). 
(2) Control variables

Inspired by the previous research, the following control variables were selected [18]:

Market size (MS)

This control variable was expressed as the logarithm of the GDP of each country, because GDP, to a certain extent, reflects the consumption capacity, production capacity and economic development level of a country [19]. If a country boasts a high purchasing power and production capacity, then the country must have a huge demand for a large market size. In this case, investors enjoy more opportunities to make profits.

Natural resources (NR)

This control variable was measured by the percentage of coal, oil, metal, and minerals in the total exports of all products in each country [20]. The abundance of natural resources is a location advantage of the host country. A country rich in natural resources can attract lots of resource-seeking FDI investors. The missing data on some countries in a few years were completed through mean interpolation.

Technological resources (TR)

This control variable was measured by the percentage of high-tech products in the total exports of all products in each country. It is generally believed that a country with advanced technologies, mature industry, and developed economy is a magnet for strategic asset-seeking FDIs. The missing data on some countries in a few years were completed through nearestneighbor interpolation.

Political stability (PS)

This control variable was measured by the percentage of a country's advantage in political stability over other countries in the world. The higher the percentage, the more stable the politics in the country [21]. The index value was calculated based on the political stability score in the Worldwide Governance Indicators (WGI) of the World Bank. The specific value depends on the political performance and occurrence of violent terrorist incidents in each country. If a country is politically unstable and susceptible to frequent riots, then entrepreneurs and manufacturers could go bankrupt at any time. Thus, political instability clearly inhibits the FDI inflow.

(3) Dummy variable

Whether a country is a developing country (DC) was taken as the dummy variable to distinguish the features between regions with different levels of income and development, thereby revealing the influence of business environment on FDI in different economies [22].

(4) Interaction items

The interaction terms between business environment and natural resources (DBNR) and between business environment and technological resources (DBTR) were introduced to judge whether the influence of business environment on FDI varies with different levels of natural resources and technological resources. To prevent multicollinearity, the business environment, natural resources, and technological resources were decentralized.

\subsection{Model testing}

\subsubsection{Unit root tests}

Two panel datasets were used in this research: the panel dataset 1 on the 26 countries in 2005-2018 without decomposing the business environment into subfactors, and the panel dataset 2 on these country in the same period with the business environment decomposed into subfactors. Both of them are balanced panels. Levin-Lin-Chu (LLC) test (suitable for same roots) and Im-Pesaran-Shin test (suitable for different roots) were applied, with the existence of unit roots as the null hypothesis. The test results are shown in Table 1.

Table 1. The results of unit root tests

\begin{tabular}{cccc}
\hline Method & Variable & Statistic & P-value \\
\hline \multirow{6}{*}{ LLC } & FDI & -5.6612 & 0.0000 \\
& DB & -2.1258 & 0.0168 \\
& MS & -0.1841 & 0.4270 \\
& DMS & -12.0014 & 0.0000 \\
& NR & -4.2275 & 0.0000 \\
& TR & -3.8037 & 0.0001 \\
& PS & -2.0163 & 0.0219 \\
IPS & DBNR & -2.2123 & 0.0135 \\
& DBTR & -2.7511 & 0.0030 \\
& MS & 1.2460 & 0.8936 \\
& DMS & -7.0247 & 0.0000 \\
\hline
\end{tabular}

As shown in Table 1, MS is the only first-order integrated sequence. Because it is not the dependent variable, this does not affect the empirical results. Thus, the original nonstationary sequence of MS was replaced by the first-order differential sequence (DMS) to obtain a stationary sequence.

\subsubsection{Multicollinearity test}

The variance inflation factor (VIF) was selected as the index of the multicollinearity test. The test results (Table 2) show that the maximum of VIF did not surpass 10, indicating that the variables do not have multicollinearity.

Table 2. The results of multicollinearity test

\begin{tabular}{ccc}
\hline Samples/variables & Mean VIF & Maximum VIF \\
\hline $\begin{array}{c}\text { (1) All samples and 5 } \\
\text { main variables }\end{array}$ & 2.15 & 3.23 \\
$\begin{array}{c}\text { (2) All samples, 5 main } \\
\text { variables, and dummy } \\
\quad \text { variable }\end{array}$ & 2.39 & 3.26 \\
$\begin{array}{c}\text { (3) All samples, 5 main } \\
\text { variables, dummy }\end{array}$ & 2.74 & 4.98 \\
$\quad$ variables, and two & & \\
interaction terms \\
(4) All samples, 4 main \\
variables, and 10 \\
subfactors of DB
\end{tabular}

\subsection{Model construction}

The following formulas were set up to empirically analyze the degree of influence of business environment on the FDI inflow of each country under different conditions:

$$
\begin{gathered}
F D I_{i t}=\beta_{0}+\beta_{1} D B_{i t}+\beta_{r} X_{i t}+\varepsilon_{i t} \\
F D I_{i t}=\beta_{0}+\beta_{1} D B_{i t}+\beta_{r} X_{i t}+\beta_{6} D C_{i t}+\varepsilon_{i t} \\
F D I_{i t}=\beta_{0}+\beta_{1} D B_{i t}+\beta_{r} X_{i t} \\
+\beta_{7} D B N R_{i t}+\beta_{8} D B T R_{i t}+\varepsilon_{i t} \\
F D I_{i t}=\beta_{0}+\beta_{1} D B s u b_{i t}+\beta_{r} X_{i t}+\varepsilon_{i t}
\end{gathered}
$$

where, $i$ is the serial number of countries; $\mathrm{t}$ is the year; $X$ is a control variable; $\varepsilon$ is a random error term; $\beta_{0}$ is a constant term; $\beta_{r}(\mathrm{r}=1,2,3,4,5,6,7,8)$ is the regression coefficients of the influencing factors. 
Formula (1) measures the influence of overall business environment on FDI inflow; Formula (2) introduces the dummy variable to measure the influence of the business environment in different economies on FDI inflow; Formula (3) further measures the influence of natural and technological resources on FDI; Formula (4) refines the business environment, and measures the influence of six subfactors on FDI, namely, startup, credit acquisition, tax payment, protection of small and medium investors, construction permit, and cross-border trade.

\section{EMPIRICAL ANALYSIS}

Regression analysis was conducted on Stata 15. The influence of heteroscedasticity was eliminated using robust and clustered standard errors. The empirical results are shown in Table 3.

Table 3. The empirical results

\begin{tabular}{|c|c|c|c|c|c|}
\hline & $\begin{array}{c}(1) \\
\text { ols_vce }\end{array}$ & $\begin{array}{l}(2) \\
\text { re vce }\end{array}$ & $\begin{array}{c}(3) \\
\text { fe vce }\end{array}$ & $\begin{array}{l}\text { (4) } \\
\text { re }\end{array}$ & $\begin{array}{l}\text { (5) } \\
\text { fe }\end{array}$ \\
\hline DB & $\begin{array}{l}0.0417 \\
(1.27)\end{array}$ & $\begin{array}{c}0.0305^{* *} \\
(2.47)\end{array}$ & $\begin{array}{c}0.0306^{* *} \\
(2.39)\end{array}$ & $\begin{array}{c}0.0305^{* * *} \\
(7.27)\end{array}$ & $\begin{array}{c}0.0306^{* * *} \\
(7.19)\end{array}$ \\
\hline DMS & $\begin{array}{l}-2.921 \\
(-0.93)\end{array}$ & $\begin{array}{l}-0.784 \\
(-1.38)\end{array}$ & $\begin{array}{l}-0.788 \\
(-1.36)\end{array}$ & $\begin{array}{l}-0.784 \\
(-1.37)\end{array}$ & $\begin{array}{l}-0.788 \\
(-1.37)\end{array}$ \\
\hline NR & $\begin{array}{l}0.0117 \\
(0.83)\end{array}$ & $\begin{array}{c}0.0120^{*} \\
(1.85)\end{array}$ & $\begin{array}{c}0.0121^{*} \\
(1.84)\end{array}$ & $\begin{array}{c}0.0120^{* *} \\
(2.52)\end{array}$ & $\begin{array}{c}0.0121^{* *} \\
(2.41)\end{array}$ \\
\hline $\mathrm{TR}$ & $\begin{array}{c}0.0361^{* *} \\
(2.71)\end{array}$ & $\begin{array}{c}0.0327^{* * *} \\
(3.69)\end{array}$ & $\begin{array}{c}0.0321^{* * * *} \\
(3.59)\end{array}$ & $\begin{array}{c}0.0327^{* * *} \\
(6.88)\end{array}$ & $\begin{array}{c}0.0321^{* * * *} \\
(6.39)\end{array}$ \\
\hline PS & $\begin{array}{c}- \\
0.00230 \\
(-0.23)\end{array}$ & $\begin{array}{c}0.0147^{* *} \\
(2.22)\end{array}$ & $\begin{array}{c}0.0162^{* *} \\
(2.22)\end{array}$ & $\begin{array}{c}0.0147^{* * *} \\
\quad(4.82)\end{array}$ & $\begin{array}{c}0.0162^{* * *} \\
(5.06)\end{array}$ \\
\hline _cons & $\begin{array}{l}3.242^{*} \\
(1.90) \\
\end{array}$ & $\begin{array}{c}3.120^{* * *} \\
(2.99)\end{array}$ & $\begin{array}{c}3.055^{* * *} \\
(3.11)\end{array}$ & $\begin{array}{c}3.120^{* * *} \\
(6.48) \\
\end{array}$ & $\begin{array}{c}3.055^{* * *} \\
(6.89) \\
\end{array}$ \\
\hline$N$ & 338 & 338 & 338 & 338 & 338 \\
\hline r2 & 0.466 & & 0.361 & & 0.361 \\
\hline r2_a & 0.458 & & 0.351 & & 0.298 \\
\hline $\mathrm{F}$ & 4.314 & & 6.707 & & 34.64 \\
\hline $\mathrm{p}$ & 0.00575 & 0.00000143 & 0.000434 & $4.40 \mathrm{e}-39$ & $7.16 \mathrm{e}-81$ \\
\hline
\end{tabular}

\subsection{Influence of overall business environment on FDI}

First, the entire samples were subject to ordinary least squares (OLS) regression, estimation by random effects model, and estimation by fixed effects model. The LM test results rejected the null hypothesis, suggesting that random effects model should be selected. The Hausmann test accepted the null hypothesis. Thus, overidentification test was carried out, and the same result was obtained. Hence, the random effects model was selected for regression by generalized least squares (GLS) method:

$$
\begin{gathered}
F D I_{i t}=3.120+0.0305 D B_{i t} \\
-0.784\left(M S_{t}-M S_{t-1}\right)+0.0120 N R \\
+0.0327 T R+0.0147 P S
\end{gathered}
$$

The coefficients of NR, DB, PS, and TR were significantly positive, indicating that the FDI inflow of a country is positively correlated with natural resources, business environment, political stability, and technological resources. Therefore, a good overall business environment can promote the FDI inflow, which verifies the results of previous studies.
4.2 Results after adding dummy variable and interaction terms

After adding dummy variable and interaction terms, the regression results can be respectively expressed as:

$$
\begin{gathered}
F D I_{i t}=2.603+0.0279 D B_{i t}-0.622\left(M S_{t}-\right. \\
\left.M S_{t-1}\right)+0.0110 N R+0.0376 T R+0.0285 P S \\
F D I_{i t}=3.315+0.0383 D B_{i t}-0.790\left(M S_{t}-\right. \\
\left.M S_{t-1}\right)+0.00712 N R+0.0244 T R \\
+0.0122 P S-0.000922 D B N R- \\
0.000877 D B T R
\end{gathered}
$$

After adding the dummy variable, the value and significance level of DB coefficient decreased; the NR coefficient was no longer significant; the TR and PS coefficients increased, and the latter witnessed a growth in significance level. The results show that, after the host country is identified as a developing country, the promoting effects of political stability and technological resources on FDI will increase, while the influence of business environment on FDI will decline. This is probably because enterprises tend to examine factors related to investment risks, e.g., political stability and technological resources, before investing in developing countries. Compared with the rate of return, the ease of investment is no longer the top consideration (Table 4).

Table 4. The test results on model selection

\begin{tabular}{ccc}
\hline Method & Statistic & Value \\
\hline Lagrange Multiplier (LM) test & $\mathrm{P}$ & 0.0000 \\
Hausman test & $\mathrm{P}$ & 0.7037 \\
Overidentification test & $\mathrm{P}$ & 0.5842 \\
\hline
\end{tabular}

Table 5. The regression results after adding dummy variable and interaction terms

\begin{tabular}{ccc}
\hline & $(6) \mathrm{DC}$ & $(7)$ Interaction terms \\
\hline \multirow{2}{*}{ DB } & $0.0279^{*}$ & $0.0383^{* * *}$ \\
& $(1.86)$ & $(5.23)$ \\
DMS & -0.622 & -0.790 \\
& $(-0.88)$ & $(-1.36)$ \\
NR & 0.0110 & $0.00712^{* *}$ \\
& $(1.35)$ & $(2.02)$ \\
TR & $0.0376^{* * *}$ & $0.0244^{* * *}$ \\
& $(4.18)$ & $(3.29)$ \\
PS & $0.0285^{* * *}$ & $0.0122^{*}$ \\
& $(3.10)$ & $(1.87)$ \\
DBNR & & $-0.000922^{* * *}$ \\
& & $(-3.43)$ \\
DBTR & & $-0.000877^{* * *}$ \\
& $2.603^{* *}$ & $(-2.95)$ \\
cons & $(2.33)$ & $3.315^{* * *}$ \\
& 143 & $(4.67)$ \\
\hline$N$ & $2.32 \mathrm{e}-11$ & $1.38 \mathrm{e}-27$ \\
p & & \\
\hline Note: ${ }^{*} p<0.1,{ }^{* *} p<0.05$, and $^{* * *} p<0.01$.
\end{tabular}

After adding the interaction terms, the value and significance level of DB coefficient both increased. On the contrary, the coefficients of NR and TR decreased. The two interaction terms, namely, DBNR and DBTR, were significant on the level of 0.01 , but with small negative values. These confirm that the influence of business environment on FDI inflow indeed depends on the resource level of the host 
country; the abundance of natural and technological resources will both suppress that influence (Table 5).

\subsection{Results after adding subfactors of business environment}

Table 6 displays the regression results after adding the six subfactors of business environment. It can be seen that the coefficients of SU, CA, TP, IP, CP, and CT were significantly positive, indicating that the six subfactors can indeed promote FDI inflow. The relatively large coefficients of IP and CT signify the relatively large promoting effect of the two subfactors on FDI.

Four other subfactors were also imported to the regression model. The results show that the coefficients of all subfactors were significantly positive, except for PR, whose coefficient was negative. Among them, ES and IN had relatively large coefficients, an evidence for their relatively strong promoting effect on FDI inflow.

When all subfactors were considered in regression, the coefficients that were significant either become insignificant or smaller. A possible reason is that the promoting effect of each independent factor is dilute by too many independent factors. In fact, the annual briefings by the World Bank on business environment show that no country improves all indices at the same time. It is only possible to improve one or two indices. Hence, the sample features could be another reason for the coefficient changes.

Table 6. The regression results after adding subfactors of business environment

\begin{tabular}{|c|c|c|c|c|c|c|}
\hline & (8) 01 & (9) 02 & (10) 03 & (11) 04 & (12) $\quad 05$ & (13) 06 \\
\hline SU & $\begin{array}{c}0.00957^{* *} \\
(2.44)\end{array}$ & & & & & \\
\hline $\mathrm{CA}$ & & $\begin{array}{c}0.00976^{* * *} \\
(4.00)\end{array}$ & & & & \\
\hline TP & & & $\begin{array}{c}0.00600^{* *} \\
(2.17)\end{array}$ & & & \\
\hline PI & & & & $\begin{array}{c}0.0177^{* * *} \\
(3.29)\end{array}$ & & \\
\hline $\mathrm{CP}$ & & & & & $\begin{array}{c}0.00869^{* * *} \\
(4.08)\end{array}$ & \\
\hline CT & & & & & & $\begin{array}{c}0.0117^{* * *} \\
(4.89)\end{array}$ \\
\hline _cons & $\begin{array}{c}5.235^{* * *} \\
(8.99)\end{array}$ & $\begin{array}{c}5.812^{* * *} \\
(8.14) \\
\end{array}$ & $\begin{array}{c}5.346^{* * *} \\
(8.35) \\
\end{array}$ & $\begin{array}{c}4.897^{* * *} \\
(5.96) \\
\end{array}$ & $\begin{array}{c}5.387^{* * *} \\
(7.57) \\
\end{array}$ & $\begin{array}{c}4.977^{* * *} \\
(7.18) \\
\end{array}$ \\
\hline$N$ & 130 & 130 & 130 & 130 & 130 & 130 \\
\hline $\mathrm{p}$ & $1.94 \mathrm{e}-31$ & $3.16 \mathrm{e}-14$ & $1.90 \mathrm{e}-22$ & $2.05 \mathrm{e}-20$ & $2.86 \mathrm{e}-26$ & $1.19 \mathrm{e}-36$ \\
\hline
\end{tabular}

\subsection{Robustness test}

The business environment index with a phase lag was imported to test the robustness of the model. The regression results (Table 6) show that the coefficient of no independent variable changed in direction or significance. Thus, our model is sufficiently robust.

Table 6. The results of robustness test

\begin{tabular}{|c|c|c|c|c|c|c|c|c|c|}
\hline & DB & DMS & NR & TR & PS & L.db & cons & $N$ & $\mathrm{p}$ \\
\hline (2) & $0.0305^{* *}$ & -0.784 & $0.0120^{*}$ & $0.0327^{* * *}$ & $0.0147^{* *}$ & & $3.120^{* * *}$ & & \\
\hline re_vce & $(2.47)$ & $(-1.38)$ & $(1.85)$ & (3.69) & $(2.22)$ & & (2.99) & 338 & 0.00000143 \\
\hline$(\overline{14})$ & & $-0.956^{*}$ & $0.0124^{*}$ & $0.0329^{* * *}$ & $0.0153^{* *}$ & $0.0290^{* * *}$ & $3.205^{* * *}$ & 338 & 0000000564 \\
\hline $\operatorname{lag} 1$ & & $(-1.85)$ & $(1.81)$ & $(3.80)$ & (2.38) & $(2.80)$ & (3.29) & & \\
\hline
\end{tabular}

\section{CONCLUSIONS}

The global economic slowdown causes stagnation and even shrinking of FDI scale. The FDI inflow is no longer solely affected by economic factors. Many noneconomic factors, such as policies and institution, now play an important role in FDI inflow. From theoretical and empirical perspectives, this paper quantifies and qualifies the influence of business environment in different countries over the FDI. The FDI stock was taken as the dependent variable; the DB was chosen as the core independent variable, and decomposed into multiple subfactors; several factors, namely, MS, NR, TR, and PS, were adopted as control variables. The FDI stock in each country was obtained from United Nations Conference on Trade and Development (UNCTAD); the scores of DB and its subfactors were downloaded from the World Bank reports Doing Business; the data on the control variables were acquired from the WGI and World Development Indicators (WDI) databases of the World Bank. Then, the empirical analysis was conducted with a random effects model through GLS. The main conclusions are as follows:

(1) Facing the stagnation of global FDI, developing countries need to stable growth of FDI, and developed countries need to reverse FDI reduction. All countries should actively attract foreign investment by improving the business environment.

(2) The host country can attract more FDI inflow by improving DB, NR, TR, and PS.

(3) In developing countries, the promoting effect of DB on FDI is not necessarily stronger than that in developed countries. 
Further research is needed on larger samples. Besides, high NR and TR will, to a certain extent, inhibit FDI inflow, and reduce the attractiveness of $\mathrm{DB}$ as a location advantage.

(4) Except for PR, the improvement of other DB subfactors can attract more FDI inflow. Among them, IP, CT, ES, and IN boast relatively strong promoting effect.

On this basis, two suggestions were proposed to promote FDI inflows:

(1) The government should design a policy mix to elevate FDI inflow. Each subfactor of DB has a limited impact on FDI. The combination of multiple policies could balance the economic development. The government needs to protect small investors, ensure the transparency of investment information, and treat local and multinational enterprise equally. To lower import-export cost, the government should also facilitate cross-border trade by expediting customs clearance and reducing the files needed for clearance. In addition, industrial enterprises should be provided with stable and reliable electricity at a more favorable price. Furthermore, the government needs to reduce the time and cost of handling insolvency, ease the tax burden on enterprises, and simplify the financing formalities. Moreover, the central government is advised to publish business environment reports regularly, so that local governments can make up for the shortcomings in the region. The key to improving business environment is to provide convenience to enterprises, optimize government performance, reduce the government procedures required for enterprise production and operation. Thus, it would be effective to formulate reasonable laws, regulations, and rules.

(2) To avoid business risks, enterprises that "go global" must fully consider the local business environment. For different economies, differentiated investment measures ought to be designed. According to the actual situation, the enterprises should examine the SU, CP, ES, PR, CA, IP, TP, $\mathrm{CT}, \mathrm{CE}$, and IN in the host country, as well as their cross effects. Besides, a good investment management system is a good tool to avoid risks in OFDI. Thus, it is necessary to deepen the institutional reform, and relax the restrictions on the business and foreign exchange of OFDI. Concerning enterprises and individuals, the government should encourage residents to optimize resource allocation in the international market diversify investment risks, and increase economic returns, while avoiding risks and ensuring investment efficiency.

\section{REFERENCES}

[1] Dunning, J.H. (1998). Location and the multinational enterprise: A neglected factor? Journal of International Business $\quad$ Studies, 29(1): 45-66. https://doi.org/10.1057/palgrave.jibs.8490024

[2] Asiedu, E. (2006). Foreign direct investment in Africa: The role of natural resources, market size, government policy, institutions and political instability. World Economy, 29(1): 63-77. https://doi.org/10.1111/j.14679701.2006.00758.x

[3] Song, L.F., Wu, H. (2018). Risks of host countries, natural resources and state-owned firms' ODI. Journal of International Trade, (3): 149-162.

[4] Yan, R.F., Liu, C.B. (2012). The determinants of producer services FDI in China. Journal of International Trade, (11): 107-116.

[5] Markusen, J.R. (2001). Contracts, intellectual property rights, and multinational investment in developing countries. Journal of International Economics, 53(1): 189-204. https://doi.org/10.1016/S0022-1996(00)000581

[6] Ismail, N.W. (2009). The determinant of foreign direct investment in ASEAN: A semi-gravity approach. Transition Studies Review, 16(3): 710. https://doi.org/10.1007/s11300-009-0103-0

[7] Belgibayeva, A., Plekhanov, A. (2019). Does corruption matter for sources of foreign direct investment? Review of World Economics, 155(3): 487-510. https://doi.org/10.1007/s10290-019-00354-1

[8] Berger, A., Busse, M., Nunnenkamp, P., Roy, M. (2013). Do trade and investment agreements lead to more FDI? Accounting for key provisions inside the black box. International Economics and Economic Policy, 10(2): 247-275. https://doi.org/10.1007/s10368-012-0207-6

[9] Acemoglu, D., Johnson, S., Robinson, J.A. (2005). Institutions as a fundamental cause of long-run growth. Handbook of Economic Growth, 1: 385-472. https://doi.org/10.1016/S1574-0684(05)01006-3

[10] Blonigen, B.A. (2005). A review of the empirical literature on FDI determinants. Atlantic Economic Journal, 33(4): 383-403. https://doi.org/10.1007/s11293005-2868-9

[11] Kolstad, I., Wiig, A. (2012). What determines Chinese outward FDI? Journal of World Business, 47(1): 26-34. https://doi.org/10.1016/j.jwb.2010.10.017

[12] Wang, C., Hong, J., Kafouros, M., Boateng, A. (2012). What drives outward FDI of Chinese firms? Testing the explanatory power of three theoretical frameworks. International Business Review, 21(3): 425-438. https://doi.org/10.1016/j.ibusrev.2011.05.004

[13] Jayasuriya, D. (2011). Improvements in the World Bank's ease of doing business rankings: Do they translate into greater foreign direct investment inflows? Policy Research Working Papers. https://doi.org/10.1596/18139450-5787

[14] Morris, R., Aziz, A. (2011). Ease of doing business and FDI inflow to Sub - Saharan Africa and Asian countries. Cross Cultural Management: An International Journal, 18(4): 400-411. https://doi.org/10.1108/13527601111179483

[15] Contractor, F.J., Dangol, R., Nuruzzaman, N., Raghunath, S. (2020). How do country regulations and business environment impact foreign direct investment (FDI) inflows? International Business Review, 29(2): 101640. https://doi.org/10.1016/j.ibusrev.2019.101640

[16] Saini, N., Singhania, M. (2018). Determinants of FDI in developed and developing countries: A quantitative analysis using GMM. Journal of Economic Studies, 45(2): 348-382. https://doi.org/10.1108/JES-07-20160138

[17] Dunning, J.H. (1977). Trade, location of economic activity and the MNE: A search for an eclectic approach. The International Allocation of Economic Activity, 395418. https://doi.org/10.1007/978-1-349-03196-2_38

[18] Corcoran, A., Gillanders, R. (2015). Foreign direct investment and the ease of doing business. Review of World Economics, 151(1): 103-126. https://doi.org/10.1007/s10290-014-0194-5

[19] Ahlquist, J.S., Prakash, A. (2010). FDI and the costs of contract enforcement in developing countries. Policy Sciences, 43(2):

181-200. 
https://doi.org/10.1007/s11077-009-9093-3

[20] Shetty, A., Manley, J., Kyaw, N. (2019). The impact of exchange rate movements on mergers and acquisitions FDI. Journal of Multinational Financial Management, 52: 100594. https://doi.org/10.1016/j.mulfin.2019.100594

[21] Nondo, C., Kahsai, M.S., Hailu, Y.G. (2016). Does institutional quality matter in foreign direct investment?
Evidence from Sub-Saharan African countries. African Journal of Economic and Sustainable Development, 5(1): 12-30. https://doi.org/10.1504/AJESD.2016.074441

[22] Sabir, S., Rafique, A., \& Abbas, K. (2019). Institutions and FDI: evidence from developed and developing countries. Financial Innovation, 5(1): 8. https://doi.org/10.1186/s40854-019-0123-7 